\title{
Molecular identification of new circulating Hyalomma asiaticum asiaticum from sheep and goats in Duhok governorate, Iraq
}

\author{
S.S. Ismael ${ }^{\mathbb{D}}$ and L.T. Omer \\ Department of Microbiology, College of Veterinary Medicine, University of Duhok, Duhok, Iraq
}

\begin{tabular}{l} 
Article information \\
\hline Article history: \\
Received December 29, 2019 \\
Accepted February 7, 2020 \\
Available online September 12, 2020 \\
\hline Keywords: \\
H. asiaticum asiaticum \\
Small ruminants \\
PCR \\
Phylogenetic tree \\
Duhok \\
\hline
\end{tabular}

\section{Correspondence:}

S.S. Ismael1

shameeran.ismael@uod.ac

\begin{abstract}
Because there was no such study done on identification of tick species by PCR technique in in Duhok Governorate, therefore present study was done to identify tick species by using molecular study by using of 16S rRNA and DNA sequencing. About 1000 ticks were collected from both sheep and goat, form Duhok Governorate including: Barwaria, Zakho, Sumeil, Mangeshik, Sersing, Shekhan and Akre, between May and June 2016, between April and June 2017. The result found during this study were six species under two genera of the hard ticks were identified by molecular study and sequencing including: three species were under the genus Hyalomma and three species were under the genus Rhipiciphalus that infect small ruminants in Duhok governorate from these species a new species under the Hylomma genra (Hyalomma asiatium asiaticum) with accession number (MN594484), was first time reported in Duhok governorate. Also phylogenetic tree was constructed depend on the $16 \mathrm{~S}$ rRNA.
\end{abstract}

DOI: 10.33899/ijvs.2020.126330.1298, C2021, College of Veterinary Medicine, University of Mosul.

This is an open access article under the CC BY 4.0 license (http://creativecommons.org/licenses/by/4.0/).

\section{Introduction}

Tick is obligate ectoparasite that infests both animal and human and causing many diseases, due to they act as a vector of some pathogens including: protozoa, bacteria and virus (13 ). There are about 878 tick species; most of these are under the two famous families including: Ixodidae and Argasidae (4). The main morphological features of the hard tick, is the present of scutum, which covered the whole dorsal surface of male, while just covered a short portion of female, while it is missing in the family Argasidae and have a leathery body (5). The family Ixodiae has been classified into two major group prostriata and metastriata. The first group, Prostriata that include only the Ixodid and is considered the largest genus and relatively have 217 known species and the other ticks are arranged under the second group Metastriata including Amblyomma, Anocentor, Apanomma, Haemaphysalis, Hyalomma, Rhipicephalus, Boophilus and Dermacentar (6). 16S rRNA genes for molecular recognition and phylogenetic analysis of ticks are well known barcoding genes (7).
During this study $16 \mathrm{~S}$ rRNA gene was used for the identification of species of hard ticks that infested sheep and goats among Duhok governorate, Iraq. Because there was no such study done on identification of tick species by PCR technique in north of Iraq and particularly in Duhok governorate, Iraq.

\section{Materials and methods}

\section{Sample collection}

About 1000 ticks were collected from both sheep and goats 500 and 500 respectively, from Duhok governorate including: Barwaria, Zakho, Sumeil, Mangeshik, Sersing, Shekhan and Akre, Iraq, between May and June 2016, between April and June 2017.

\section{Microscopic examination}

All ticks were examined at lab under dissecting microscope with the aid of morphological key, then grouped into pools according to genus and were preserved in $70 \%$ of ethanol $(8,9)$. 


\section{Homogenizing of whole ticks}

From each group two ticks were taken and were washed with ethanol with different concentration $10 \%, 30 \%, 50 \%$ and $70 \%$ for one hour for each concentration and then twice in PBS.

Then each tick was put in a clean sterile eppendrof tube and added $0.5 \mathrm{ml}$ of PBS and homogenized by portable homogenizer for 1 minute and then was centrifuged at 1200 rpm for 10 minutes, then transferred the supernatant and collected within a new clean eppendrof tube and stored at $18^{\circ} \mathrm{C}$ till DNA extraction.

\section{Extraction of DNA from ticks}

Extraction of whole genome form tick DNA was done by using special tissue kit, DNA-Sorb-AM nucleic acid extraction kit (AmpliSens ${ }^{\circledR}$, Russia).

The purity and quality of tick DNA samples was evaluated by using a nanodrop spectrophotometer and by running of samples on gel electrophoresis, these was done by preparing $1 \%$ of agarose gel (10).

\section{Molecular identification of hard ticks}

In this study, we used one type of primer: the 16S rRNA gene fragment of size $460 \mathrm{bp}$ ), was able to catch different species of hard tick spp., foreword 5'-CCG GTC TGA ACT CAG ATC AAG T-3' and reverse 5'-GCT CAA TGA TTT TTT AAA TTG CTG T-3'(11).

In this study, the PCR reactions were performed in a final volume of $25 \mu \mathrm{l}$ of green master mix (2X) (Promega, USA or or GeNet Bio master mix), which contains (PCR buffer, Taq DNA polymerase, dNTPs, and $\mathrm{MgCl} 2) .10 \mathrm{pmol} / \mu \mathrm{l}$ of each forward and reverse primer.

The PCR reactions were conducted at a final $25 \mu 1$ rate. There was a $12.5 \mu 1$ of GeNet Bio master mix, $1 \mu 1$ from both forward and reverse primers, $2 \mu 1$ of Template DNA and Complete the volume to $25 \mu \mathrm{l}$ with added of $8.5 \mu \mathrm{l}$ nucleasefree water. According to Mangold et al. (11), the cycler state of PCR was defined as outlined in table 1.

Eventually, for 1:40 minutes, $10 \mu \mathrm{l}$ of PCR products were visualized under UV on $1 \%$ agarose gel with 85 Volts (Table 1).

Table 1: The thermocycler program for $16 \mathrm{~S}$ rRNA

\begin{tabular}{lccc}
\hline Process & ${ }^{\circ} \mathrm{C}$ & Time & No. cycles \\
\hline Initial denaturation & $95^{\circ} \mathrm{C}$ & 5 Minute & 1 \\
Denaturation & $95^{\circ} \mathrm{C}$ & 30 Seconds & \\
Annealing & $55^{\circ} \mathrm{C}$ & 30 Seconds & 35 cycle \\
Extension & $72^{\circ} \mathrm{C}$ & 30 Seconds & 1 \\
Final extension & $72^{\circ} \mathrm{C}$ & 5 Minutes & 1 \\
\hline
\end{tabular}

\section{Results}

\section{PCR technique}

Pure DNA was extracted from 150 ticks by using special tissue extraction kit, extraction package for DNA-sorb-AM nucleic acid (AmpliSens ${ }^{\circledR}$, Russia). It was amplified by using PCR and visualized by using UV. 60 samples from 150 were positive with size $460 \mathrm{bp}$ after $16 \mathrm{~S}$ rRNA amplification and have got clear bands on agarose gel $1 \%$ and electrophoresis. While some identified ticks and engorged females by microscope did not give bands (Figure 1) (Table 2).

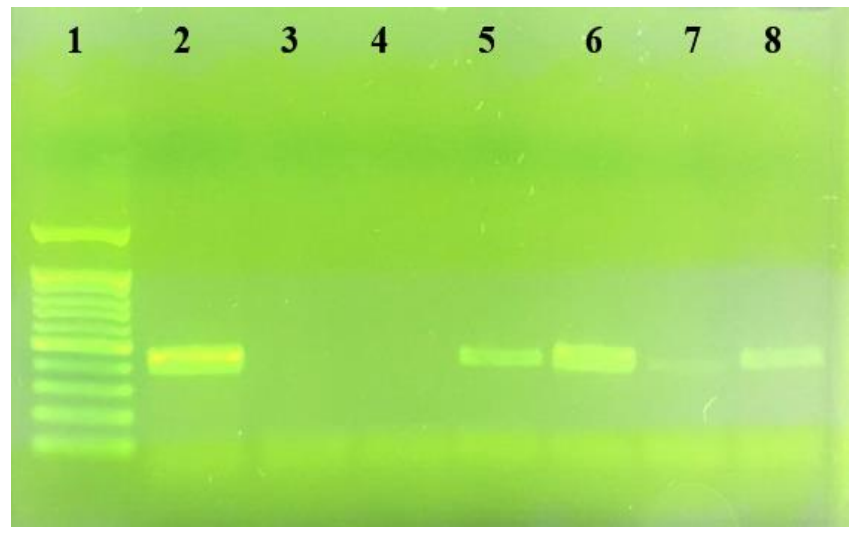

Figure 1: PCR products of hard tick $16 \mathrm{~S}$ rRNA gene. $100 \mathrm{bp}$ loading DNA marker and lane 2-5-6-7 and 8 samples with $460 \mathrm{bp}$ on agarose $1.5 \%$.

Table 2: PCR results of hard tick in Duhok governorate, Iraq

\begin{tabular}{ccccc}
\hline $\begin{array}{c}\text { Sample } \\
\text { size }\end{array}$ & $\begin{array}{c}\text { Gene } \\
\text { used }\end{array}$ & $\begin{array}{c}\text { Size } \\
(\mathrm{Bp})\end{array}$ & $\begin{array}{c}\text { Positive } \\
\text { cases } \\
\text { No. }\end{array}$ & $\%$ \\
\hline 150 & $\begin{array}{c}16 \mathrm{~S} \\
\text { Rrna }\end{array}$ & 460 & 60 & $40 \%$ \\
\hline
\end{tabular}

\section{Sequencing of 16S rRNA gene fragment}

The sequencing was performed at Macrogen Company, Korea. The sequences were analyzed, checked and aligned using BioEdit sequence alignment editor 7 (Isis Pharmaceuticals, Inc., Carlsbad, CA, USA). The sequence was submitted to GenBank (accession number from genBank as following: MN594483.1, MN594484.1, MN594485.1, MN594486, MN594487, MN594488, MN594489, MN594490, MN594491, MN594492.1, MN594493.1 and MN594494.1) (Table 3). The similarity of the sequence with homologous sequences deposited in GenBank was calculated using the "BLAST" tool on the National Center for Biotechnology Information (NCBI) website.

During this study, six species under two genera of the hard ticks were identified by molecular study and sequencing including three species were under the genus Hyalomma and three species were under the genus Rhipiciphalus that infect small ruminants in Duhok governorate from these species a new species under the Hylomma genra (Hyalomma asiatium asiaticum) with accession number (MN594484), was recently reported in Duhok governorate, Iraq were identify as (Table 3). 


\section{Phylogenetic tree and analysis}

During this analysis, MEGA 7 technology was used to construct phylogenetic relationships and neighbor-joining tree depending on the alignment of 16S rRNA sequences to evaluate the phylogenetic relationship species status of two types of ticks in this sample. Phylogenetic tree (Figure 2) is divided into two ancestors; first ancestor was divided into two clades, in which the first clad was arranged as cluster, which included Rhipicephalus turanicus MN594493, MN594483, MN594486, MN594485 and MN594487,
Ripicephalus sangiuneus MN594492 and MN594489 and using Rhipicephalus annulatus as out group. In the second ancestor, also there were two clades; the first clade was used as out group was Hyalomma asiaticum asiaticum MN594494, while the second clade was grouped as cluster which included Hyalomma marginatum MN594494 and Hyalomma analoticum analoticum MN594490 and MN594488 they were closely identical to each other therefore, they clustered with a bootstrap value of 99 .

Table 3: Genus and species of hard ticks and the GenBank accession number

\begin{tabular}{lccccc}
\hline \multirow{2}{*}{ Study Ticks } & \multirow{2}{*}{ Accession No. } & Species & $\begin{array}{c}\text { Similarity } \\
\%\end{array}$ & $\begin{array}{c}\text { References } \\
\text { Accession No. }\end{array}$ & Country \\
\hline \multirow{3}{*}{ Hyalomma } & MN594484 & Hyalomma asiaticum asiaticum & $99 \%$ & JX051079.1 & China, Mongolia \\
& MN594488 & Hyalomma anatolicum & $99 \%$ & HM176656.1 & India \\
& MN594494 & Hyalomma marginatum & $99 \%$ & L34307.1 & U.S.A \\
\hline \multirow{2}{*}{ Rhipicephalus } & MN594491 & Rhipicephalus annulatus & $99 \%$ & MF946466.1 & India \\
& MN594492 & Rhipicephalus sanguineus & $99 \%$ & KX553960.1 & French \\
& MN594493 & Rhipicephalus turanicus & $100 \%$ & KY583065.1 & China \\
\hline
\end{tabular}

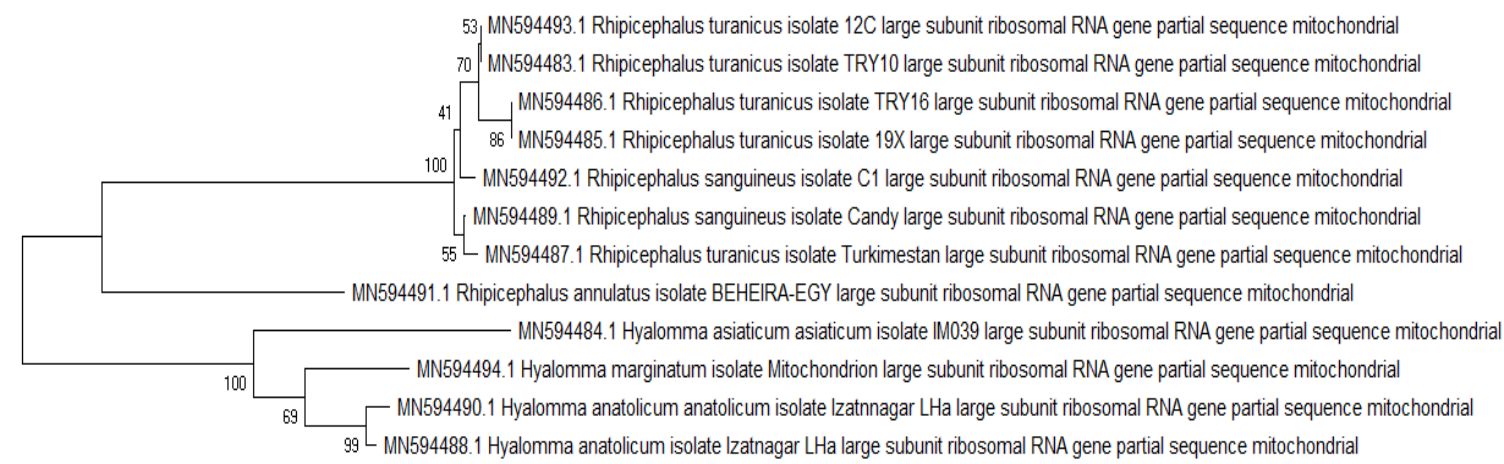

0.020

Figure 2: Phylogenetic Tree among Tick species infested small ruminants in Duhok governorate, Iraq.

\section{Discussion}

This study is considered the first study done in Duhok on the identification of hard tick species infesting among small ruminants by using $16 \mathrm{~S}$ rRNA with the aid of PCR. In this study the distribution of Rhipicephalus spp., came first. There were several studies that support all these species in Duhok, Iraq by Omer et al. (12). There was another article supports the same species that found in mountainous areas of Golestan province, Iran by Sarani et al. (13). However, this study does not correspond with Al-Fatlawi et al. (14), who recorded that Hyalomma spp., were more predominant in the south of Iraq. Hyalomma anatolicum, Rhipicephalus turanicus and Rhipicephalus sanguineus were recorded by Mustafa et al. (15) in Sulaimani province north of Iraq. It was also recorded in the north of Iraq by (16) who reported some species of hard ticks were included: $H$. atolicum anatolicum, H. marginatum marginatum, and Rhipecephalus appendiculatus.

Molecular study, for the first time this technique has been used in Duhok, Iraq and it's especially for the identification of tick species. One marker was used in this study: the first one was ribosomal ribonucleic acid S16 rRNA for the identification of tick species. This study used Ribonucleic acid S16 rRNA for the identification and sequencing of tick species, which is as a good marker for the identification of hard tick species to solve morphological tick identification problems.

Molecular markers such as mitochondrial 12S/16S rDNA, cytochrome oxidase subunit I (COI) and nuclear 
ribosomal ITS2 were used with great success, according to $(17,18)$. Several papers were used to establish the phylogenetic relationships between various economic effects as they develop rapidly and are inherited maternally $(19,20)$. Also sequences of mitochodrial DNA are appropriate for genetic analysis of closely related species. A research was carried out in Iraq by Al-Fatlawi et al (14) using CoxIdependent PCR and defining Hyalomma analoticum.

Same marker was used by (21) for identification of tick species in Egypt and by (22) they were also used S16 rRNA for identification of Rhipicephalus turanicus in Albania and China. Overall 150 hard ticks (male and female and engorged female) were evaluated by using S16 rRNA with PCR technique and only 65 samples from which were gave positive bands, then 20 samples were send to Korea for sequencing. Sequenced samples in this study were showed that there were six species of hard tick under two genera among small ruminants in Duhok governorate, Iraq in 20162017 including Hyalomma asiaticum asiaticum this species was isolated and sequenced for the first time in Duhok governorate, and there was no such study recorded this species in Iraq. A similar study but by microscopic identification not by molecular study and sequencing that support this study was done in the northern areas of Iraq by (23). Other species were Hyalomma anatolicum, Hyalomma marginatum, Rhipicephalus annulatus, Rhipicephalus sanguineus and Rhipicephalus turanicus. Therefore, the use of S16 rRNA is a good marker in identification of these hard tick species in this study. Same species of hard ticks were recorded in Mali, West Africa by (24). With regard to tick species, 16S rDNA has been used and has been successful in constructing phylogeny of species of hard tick and $16 \mathrm{~S}$ rRNA is helpful in building of the phylogenetic tree of hard tick species.

Overall 150 hard ticks (male and female and engorged female) were evaluated by using S16 rRNA with PCR technique and only 65 samples from which were gave positive bands, then 20 samples were sent to Korea for sequencing. Sequenced samples in this study showed that there were six species of hard tick under two genera among small ruminants in Duhok governorate in 2016-2018 including Hyalomma asiaticum asiaticum species, which was isolated and sequenced for the first time Duhok, Iraq and in Duhok province, Iraq, there was no such a study that recorded this species, Hyalomma anatolicum, Hyalomma marginatum, Rhipicephalus annulatus, Rhipicephalus sanguineus and Rhipicephalus turanicus. Therefore, the use of S16 rRNA is a good marker in the identification of these hard tick species in this study. Same species of hard ticks were recorded in Mali, West Africa by Diarra et al. (25).

With regard to tick species, $16 \mathrm{~S}$ rDNA has been used and has been successful in constructing phylogeny of species of hard tick and 16S rRNA is helpful in building of the phylogenetic tree of hard tick species $(26,27)$. There was no such a study that recorded this species, Hyalomma anatolicum, Hyalomma marginatum, Rhipicephalus annulatus, Rhipicephalus sanguineus and Rhipicephalus turanicus. Therefore, the use of S16 rRNA is a good marker in the identification of these hard tick species in this study. Same species of hard ticks were recorded in Mali, West Africa by Diarra et al. (25).

Phylogenetic analysis and tree allow genetic connections between closely related species to be resolved and has become a useful tool in several fields of biological research (28). Phylogenetic tree of the present study was constructed based on 16S rRNA sequences and there was deletion, transition and transvertion in some nucleotide of sequenced samples, and these had effects on the length of the nucloetide 16s rRNA sequence of two samples, which were similar $100 \%$ to the sequences of reference within the GenBank respectively MN594483 and MN594490. The rest of sequences were identical $99 \%$ to the sequences reference. The first recorded tick in Duhok, Iraq Hyalomma asiaticum asiaticum with accession number MN594484 was similar $99 \%$ to China sequence with accession number JK051079. It differed in one nucleotide $0.1 \%$ and was as out group of cluster of Hyalomma. However, there was no similar article supported this type of tick here, and this study used molecular study and sequences analysis for the first time in Duhok, in particularly for the identification of tick species.

\section{Conclusion}

In conclusion, to our knowledge, this is the first study for the identification of Hyalomma asiaticum asiaticum from sheep and goats in Duhok governorate, Iraq by PCR and sequencing analysis.

\section{Acknowledgements}

We would like to thank Miqdad S. Ahmed Duhok Research Center, University of Duhok, for his help to facilities using laboratory of molecular biology.

\section{Conflict of Interest:}

The authors announce that the work was carried out without any commercial financial ties which could be established as a possible conflict of interest.

\section{References}

1. Mans BJ, Klerk D, Pienaar de Rm, Latif AA. A living fossil and closest relative to the ancestral tick lineage: Implications for the evolution of blood-feeding in ticks. PLoS One. 2011; 6: e23675. Doi: 10.1371/journal.pone.0023675

2. Mans BJ, Klerk de D, Pienaar de Rm, Castro de MH, Latif AA. The mitochondrial genomes of Nuttalliella namaqua (Ixodoidea: Nuttalliellidae) and Argas africolumbae (Ixodoidae: Argasidae): Estimation of divergence dates for the major tick lineages and reconstruction of ancestral blood-feeding characters. PLos One. 2012;7(11):e49461. Doi: 10.1371/39202075 
3. de la Fuente J, Estrada-Peña A, Venzal JM, Sonenshine DE. Overview: Ticks as vectors of pathogens that cause disease in humans and animals. Frontiers Biosci. 2008;13(18):6938-46. Doi: 10.2741/3200

4. Dabaja FM, Tempesta M, Bayan A, Vesco G, Gerco G, Torina A, Blanda V, La Russa F, Scimeca, S, Lelli R, Ezzedine M, Mortada H. Diversity and distribution of ticks from domestic ruminants in Lebanon. Vet Ital. 2014;1:147-155. Doi: 10.12834/VetIt.1171.6503.2

5. Barker S, Walker AR. Ticks of Australia. The species that infest domestic animals and humans. Zootaxa. 2014;3816(1): 101-144. Doi: 10.11646/zootaxa.3816.1.1

6. Nava S, Guglielmone AA, Mangold AJ. An overview of systematics and evolution of ticks. Frontiers in Biosci. 2009;14(8):2857-77. Doi: $10.2735 / 3418$

7. Lv J, Wu S, Zhang Y, Chen Y, Feng C, Yuan X. Assessment of four DNA fragments (COI, 16S rDNA, ITS2, 12S rDNA) for species identification of the Ixodida (Acari: Ixodida). Parasit Vectors. 2014;7:93. Doi: 10.1186/1756-3305-7-93

8. Balinandi S, Chitimia L, Grandi G, Nakayiki T, Kabasa W Bbira J, Lutwama JJ, Bakkes DK, Malmberg M, Mugisha L. Morphological and molecular identification of ixodid tick species (Acari: Ixodidae) infesting cattle in Uganda. Parasitol Res. 2020;119(8). Doi : 10.1007/s00436-020-06742-Z

9. Fatemian Z, Salehzadeh A, Sedaghat MM, Telmadarraiy Z, Hanafi AA, Zahirni AH. Hard tick (Acari: Ixodidae) species of livestock and their seasonal activity in Boyer-Ahmad and Dena cities of Kohgiluyeh and Boyer-Ahmad Province, Southwest of Iran. Vet World. 2018;11(9):1357-1363. Doi: 10.14202/vetworld.2018.1357-1363

10. Crowder CD, Rounds MA, Phillipson CA, Picuri JM, Matthews HE, Halverson J, Schutzer SE, Ecker DJ, Eshoo MW. Extraction of total nucleic acids from ticks for the detection of bacterial and viral pathogens. J Med Entomol. 2010;47(1):89-94. Doi: 10.1603/033.047.0112

11. Mangold AJ, Bargues MD. Mitochondrial 16S rDNA sequences and phylogenetic relationships of species of Rhipicephalus and other tick genera among Metastriata (Acari: Ixodidae). Parasitol Res. 1998;84:478-484. Doi: $10.1007 / \mathrm{s} 004360050433$

12. Omer LT, Kadir MAA, Seitzer U, Ahmed JSA. Survey of ticks (Acari: Ixodidae) on cattle, sheep and goats in the Dohuk governorate, Iraq. Parasitol Res. 2007;101:179-181. Doi: 10.1007/s00436-007-0690-9

13. Sarani M, Telmadarraiy Z, Moghaddam AS, Azam K, Mohammad Mehdi Sedaghat MM. Distribution of ticks (Acari: Ixodidae) infesting domestic ruminants in mountainous areas of Golestan province, Iran. Asian Pac J Trop Biomed. 2014;4(1):S246-S251. Doi: 10.12980/APJTB.4.2014C746

14. Al-Fatlawi MA, Ali MJ, Albayati HH. Morphological and phylogenetic study of Hyalomma anatolicum in Al-Najaf, Iraq. Iraqi J Vet Sci. 2019;32(2):261-266. Doi: 10.33899/ijvs.2019.153860

15. Mustafa BHS. Detection on ectoparasites on small ruminants and their impact on the tanning industry in Sulaimani province. Iraqi J Vet Sci. 2019;33(2):303-309. Doi: 10.33899/ijvs.2019.162995

16. Zangana IK, Ali BA, Naqid IA. Distribution of ectoparasite infested sheep and goats in Duhok province, north Iraq. Bas J Vet Res. 2013;12(1):54. Doi: 10.33762/bvetr.2013.76188

17. Barker SC. Distinguishing species and populations of Rhipicephaline ticks with its 2 ribosomal RNA. J Parasitol. 1998;84:887-892. Doi: $10.2307 / 3284614$

18. Zhu X, Gasser RB, Podolska, M, Chilton NB. Characterization of anisakid nematodes with zoonotic potential by nuclear ribosomal DNA sequences. Int J Parasitol. 1998;28:1911-1921. Doi: 10.1016/s00207519(98)00150-7

19. Brahma RK, Dixit V. Identification and characterization of Rhipicephalus (Boophilus) microplus and Haemaphysalis bispinosa ticks (Acari: Ixodidae) of North East India by ITS2 and 16S rDNA sequences and morphological analysis. Exp Appl Acarol. 2013;62:253265. Doi: 10.1007/s10493-9732-4

20. Kain DE, Sperling FA, Daly HV, Lane RS. Mitochondrial DNA sequence variation in Ixodes pacificus (Acari: Ixodidae). Heredity. 1999;83(4):378-386. Doi: 10.1038/sj.hdy.6886110
21. Norris DE, Klompen J, Keirans JE, Black WC. Population genetics of Ixodes scapularis (Acari: Ixodidae) based on mitochondrial $16 \mathrm{~S}$ and 12S genes. J Med Entomol. 1996;33:78-89. Doi: 10.1093/jmedent/33.1.78

22. Abdullah HA, El-Molla A, Salib FA, Allam, NT, Ghazy AA, Abdel SS. Morphological and molecular identification of the brown dog tick Rhipicephalus sanguineus and the camel tick Hyalomma dromedarii (Acari: Ixodidae) vectors of Rickettsioses in Egypt. Vet World. 2016;(10):1087-1101. Doi: 10.14202/vetworld.2016.1087-1101

23. Li HY, Zhao SS, Hornok S, Farkas R, Guo LP, Chen CF, Shao RF, Lv JZ, Wang YZ. Morphological and molecular divergence of Rhipicephalus turanicus tick from Albania and China. Exp Appl Acarol. 2017;73:493-499. Doi: 10.1007/s10493-017-0189-8

24. Robson J, Robb JM, Hawa NJ, Al-Wahayyib T. Ticks (Ixodoidea) of domestic animals in Iraq: Part 6. Distribution. J Med Entomol. 1969;6(2):125-127. Doi: 10.1093/jmedent/6.2.125

25. Diarra AZ, Almeras L, Berenger JL, Laroche M, Koné AK, Bocoum Z, Dabo A, Doumbo O, Raoult D, Parola P. Molecular and MALDI-TOF identification of ticks and tick-associated bacteria in Mali. PLos Negl Trop Dis. 2017;11(7):e0005762. Doi: 10.1371/journal.pntd.0005762

26. Black WC, Piesman J. Phylogeny of hard- and soft-tick taxa (Acari: Ixodida) based on mitochondrial 16S rDNA sequences. Proc Natl Acad Sci. 1994;91:10034-10038. Doi: 10.1073/pnas.91.21.10034

27. Abouelhassan EM, ElGawady HM, AbdelAal1 AA, ElGayar AK, Esteve MD. Comparison of some molecular markers for tick species identification. J Arthropod-Borne Dis. 2019;13(2):153-164. Doi: 10.18502/JAD.V13I2.1241

28. Yang Z, Rannala B. Molecular phylogenetics: Principles and practice. Nat Rev Genet. 2012;13:303-314. Doi: 10.1038/nrg3186

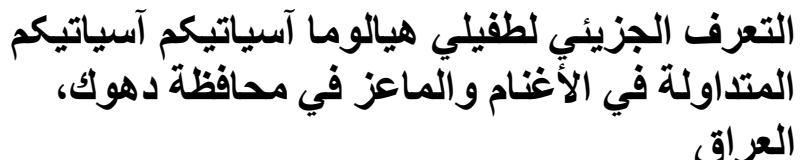

$$
\text { شرعيران سلمان إسماعيل و لقمان طيب عمر الأحياء المجهرية، كلية الطب البيطري، جامعة دهوك، دهوك، }
$$

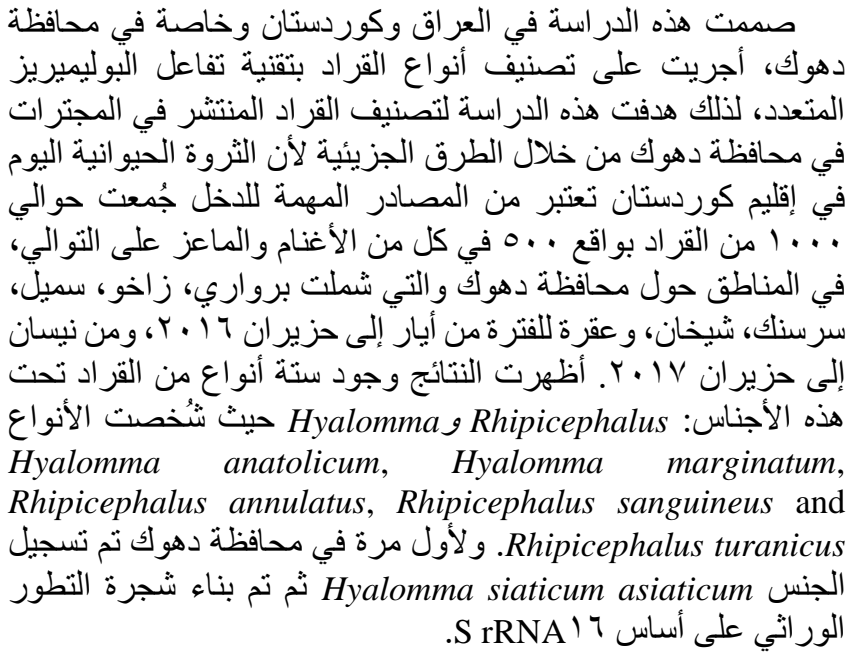

